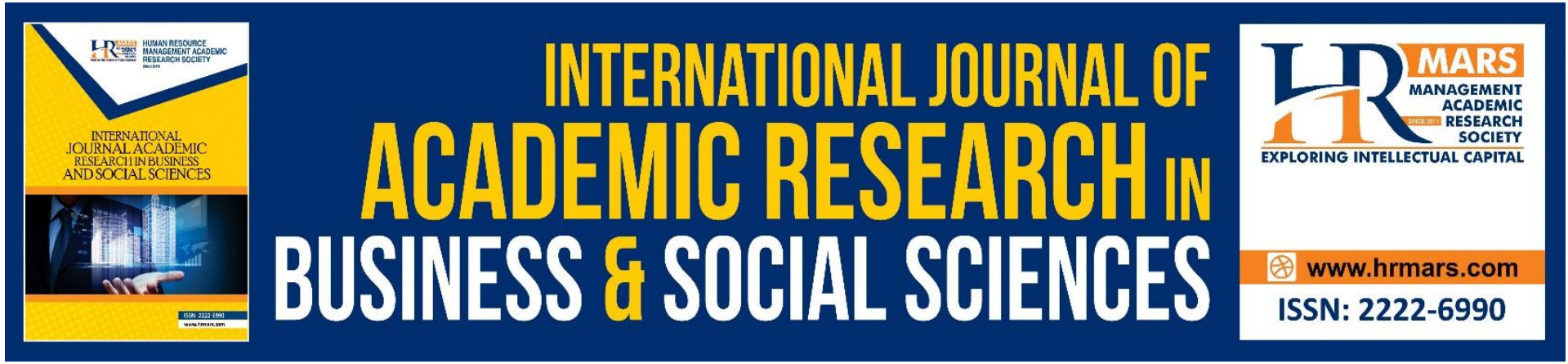

\title{
A Comparative Study of Speech Acts Between Malaysia and Singapore on the First MCO Announcements of Covid-19
}

Isai Amutan Krishnan, Geraldine De Mello, Nalini Arumugam, Puspalata C Suppiah, Sheela Paramasivam, Mohammad Nor Afandi bin Ibrahim

To Link this Article: http://dx.doi.org/10.6007/IJARBSS/v11-i8/10792 DOI:10.6007/IJARBSS/v11-i8/10792

Received: 06 June 2021, Revised: 08 July 2021, Accepted: 30 July 2021

Published Online: 12 August 2021

In-Text Citation: (Krishnan et al., 2021)

To Cite this Article: Krishnan, I. A., Mello, G. De, Nalini Arumugam, P. C. S., Paramasivam, S., \& Ibrahim, M. N. A. bin. (2021). A Comparative Study of Speech Acts Between Malaysia and Singapore on the First MCO Announcements of Covid-19. International Journal of Academic Research in Business and Social Sciences, 11(8), 992-1008.

\section{Copyright: @ 2021 The Author(s)}

Published by Human Resource Management Academic Research Society (www.hrmars.com)

This article is published under the Creative Commons Attribution (CC BY 4.0) license. Anyone may reproduce, distribute, translate and create derivative works of this article (for both commercial and non-commercial purposes), subject to full attribution to the original publication and authors. The full terms of this license may be seen at: http://creativecommons.org/licences/by/4.0/legalcode

\section{Vol. 11, No. 8, 2021, Pg. 992 - 1008}

Full Terms \& Conditions of access and use can be found at http://hrmars.com/index.php/pages/detail/publication-ethics 


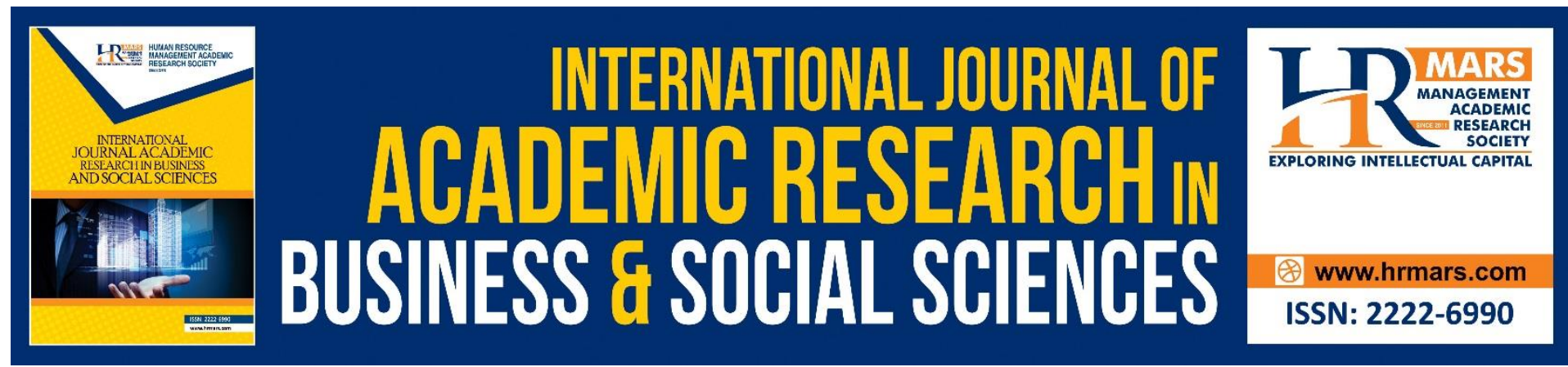

\title{
A Comparative Study of Speech Acts Between Malaysia and Singapore on the First MCO Announcements of Covid-19
}

\author{
Isai Amutan Krishnan ${ }^{1}$, Geraldine De Mello², Nalini Arumugam³ \\ Puspalata C Suppiah ${ }^{4}$, Sheela Paramasivam ${ }^{5}$, Mohammad Nor \\ Afandi bin lbrahim 6 \\ ${ }^{1}$ Faculty of Languages and Linguistics, University of Malaya, ${ }^{2,6}$ Academy of Language Studies, \\ Universiti Teknologi MARA Melaka, Malaysia, ${ }^{3,4}$ Academy of Language Studies, Universiti \\ Teknologi MARA Shah Alam, Selangor, Malaysia, ${ }^{5}$ Academy of Language Studies, Universiti \\ Teknologi MARA Negeri Sembilan, Seremban Campus, Malaysia
}

\begin{abstract}
The purpose of the study was to analyse the use of speech acts on the first announcements of Covid-19 Movement Control Order (MCO) by the Prime Ministers of Malaysia and Singapore. It was also to discover if there were differences in the forms of these announcements which affected the nation in their respective countries. This study employed a qualitative method of analysis. The MCO announcements were taken from the available open sources. The data was analysed based on Searle's framework of speech Acts. It was found that the Prime Minister of Malaysia used directive speech acts predominantly $(n=26$; $52 \%)$ as compared to the Prime Minister of Singapore ( $n=20 ; 48.8 \%)$ when they implored the nation to comply with the tighter restrictions. The findings further revealed that both Prime Ministers were not familiar with declaration speech acts as shown in their announcements due to their democratic approach in administrating their countries, they were pleading to the nation in a firmly dignified manner. There were hardly any differences between the prime ministers in using speech acts in their announcements. Nevertheless, the announcements conveyed their messages to the nation regarding the severity of the Covid-19 pandemic. This study analyses the different types of speech acts used by the Prime Ministers as they update their country while maintaining a calm situation.
\end{abstract}

Keywords: Speech Acts, MCO Announcement, Pragmatic, Prime Ministers.

\section{Introduction}

Speech acts, as referred to by Leech (1983); Nunan (1999, p.131) as "the application of language by individuals to argue, order, accept and advise". This concept of language led to the "Speech act Theory" and is now regarded as the core of deliberation in pragmatics. Conversely, Yule $(1996 ; 2014)$ stated that the speech act theory is perceived as the utterance of a sentence that implicates three varied types of action: locutionary, illocutionary and perlocutionary acts. 
The Malaysian health authorities revealed that they had detected the COVID-19 virus in several travelers arriving from China on 25 January 2020 (Sipalan \& Holmes, 2020). In response, on 12 and 13 of March 2020, the prime ministers of Malaysia and Singapore revealed their strategy to overcome the pandemic.

Bernama (2020); Awani (2020) announced on 16 March that a countrywide "Movement Control Order" (MCO) would be imposed from the 18th to 31st March 2020 for the purpose of mitigating the transmission of COVID-19. In the same manner, a MCO was put in place in Singapore but on a much earlier date.

Both prime ministers' speech acts and the MCO resulted in challenges on how to go about dealing with daily matters. Based on this, the speech and information thereafter affected the neighbouring nations in certain ways, such as feeling demotivated, unpersuaded, unresponsive and fearful. Abdullah et al (2020) stated that the pandemic has instilled panic amongst Malaysians due to the restrictions in daily activity. Therefore, the purpose of the present study was to analyse the use of speech acts in the first announcement of MCO by the two country leaders and determine the impact of these announcements on their respective nations in the long run.

\section{Literature Review}

\section{Theoretical Framework of Speech Acts}

The speech act theory proposed by Austin indicates that utterances are not only verbal expressions, but also have the force to accomplish something. Austin (1969), contends that expressions can be construed as actions. Austin's (1962) speech acts are categorised into three groups: locutionary, illocutionary, and perlocutionary acts.

Locutionary acts are actions of uttering an expression, that is the act of creating speech. Yule (2006), elucidates that locutionary acts are the fundamental act of expression or creating a relevant linguistic statement. It involves communication, such as expressing a particular vocalization or producing particular symbols, by applying certain terms and utilizing them in compliance with the grammatical conventions of a specific language. For example: "It is cold here". This expression is an example because a locutionary act creates only a single sentence and could be limited to a message. Hence, the action of expressing something is called a locutionary act.

Illocutionary acts are the nucleus of the speech act hypothesis. That is the typical strength attained in the use of that expression. An illocutionary act is perceived as the power behind expressions or sentences as shown in the example. This is referred to by Austin (1962) as the speaker achieves his or her intended goal. On the other hand, Searle (1969) considers it to be the outcome of the listener's understanding.

Searle (1979) stated that the illocutionary acts are categorised into five general classes as explained in Table 1. 
TABLE 1. Definition of Speech Acts

\begin{tabular}{ll}
\hline Categories & Definitions \\
\hline Assertives & Defines the aim or reason for the components of the assertive rank to cause \\
the speaker (in contrasting levels) to follow orders in order to establish the \\
accuracy of the spoken suggestion. These speech acts comprise of \\
declarations concerning genuine or untrue values. The terms that comprise \\
the assertive/representative are; confirming, trusting, bragging, asserting, \\
arguing, closing, refuting, predicting, notifying, informing and affirming. \\
Defines the illocutionary goal, which is the effort (they are variables of the \\
ascertainable which embraces effort) by the speaker to make the listener to \\
performa task. In these speech acts, the speaker attempts to get the listener \\
to perform an action. The terms incorporated in directives are: counseling, \\
requesting, pleading, demanding, ordering, advocating, appealing and \\
proposing. \\
Defines the illocutionary acts whose goal is to consign the speaker to some \\
upcoming event and the speech acts which produce a requirement for the \\
speaker. In other words, they oblige the speaker to perform something. The \\
expressions incorporated in the pledges are: assuring, contributing, \\
undertaking, affirming, intimidating and promising. \\
Defines the illocutionary aim of this category as the articulation of the \\
psychological condition indicated in the honesty regarding conditions \\
identified in the propositional content. Also, speech acts craft estimations \\
of psychological conditions. It portrays emotions and standpoints of the \\
speaker. The terms incorporated in expressives are: remorseful, accusing, \\
applauding, remissive, flattering, appreciating, greetings and approving. \\
Defines the features of this category as the successful accomplishment of \\
one of its parts to achieve correlation between the propositional content. \\
The speech acts inside declarative announcements are executed, while the \\
expressions incorporated in the declaratives are: assigning, fascinating, \\
rejecting, designating, abdicating and ruling.
\end{tabular}

Source: Searle (1979)

Table 1 shows the five illocutionary acts: assertives, directive, commissive, expressive, declarative. Expressing or scripting in a language when presenting speech acts of a particular variety is referred to as "illocutionary acts". This embraces giving remarks, questioning, commanding, promising, expressing regret, showing gratitude, and so on.

\section{Past Studies on Speech Acts}

Many investigations have been performed with regards to pragmatic speech acts. One of such investigations was carried out by Ayeomoni and Akinkuolere (2012); and investigated to ascertain the speech act aspects of President Umaru Yar' Adua's victory and inaugural speeches. The investigation concentrated on the pragmatic aspects of locution, illocution, and perlocution established by Austin (1962) and Searle (1976). The results revealed that the Overall Relative Frequency Percentages (ORFPs) for the chosen speeches of Umaru Musa Yar' Adua were: assertive $=60 \%$, directive $=35 \%$, expressive $=15 \%$, verdictive $=40 \%$, commissive $=30 \%$, and declarative $=20 \%$.

A similar research has been carried out by Hashim (2015), which was centered around the pragmatic meaning of locution, illocution and perlocution in the speech acts. By applying 
the hypothesis associated with the political speech by Dijk (1997, p. 13), political dialogues by Beard (2000, p. 18) and the speech acts hypothesis by Austin (1962), Hashim was able to establish the speech acts organisation for John Kerry's speeches in his Presidential Campaign in 2004 and for George Bush's Inaugural Address in 2001. Her research revealed that the total relative frequency percentages for the chosen speeches were commissive $40 \%$, assertive $35 \%$, directive $20 \%$, and expressive $5 \%$.

In the analysis of various speeches, Altikriti (2016) presented a study of the speech acts in Barack Obama's inaugural speeches (in 2009, 2013) and the last State of the Union address (in 2016). Altikriti (2016) focused on gaining more insight and determining the function of speech acts in political speeches. He applied the speech acts categorization Perloff (2003, p. 34) and modified the form by Bach, Robert and Harnish (1979) for speech nomenclature. His analysis showed that President Obama utilised more sentences that functioned as constative speech acts and less of other speech acts except assertive illocutionary acts which was applied for inducement. These studies abundantly show the crucial aspect of persuasive speech acts in political speeches and their effect on the listeners.

In another study, Danang (2012) evaluated the speech acts in Obama and McCain's interactions in 2008. The speech acts were first classified, then the substance of the illocutionary acts expressed by Barack Obama and McCain were appraised. He managed to establish five speech act classes as well as the essence of the speeches of Barack Obama and McCain in the presidential debates. Danang (2012) also described the tactics employed by the presidential candidates to convince the voters. In this election campaign, Danang (2012) had the view that the candidates were able to influence their voters by formulating more effective and deliverable undertakings in contrast with the era of President Bush's administration and communicated with more conviction about the future to gain the support of the voters.

Bushra (2015), examined the pragmatic study of commissives in certain American political speeches. The investigation was to evaluate precise commissive acts (undertaking, intimidation, assurance and promise) in certain chosen American political texts. A language study was undertaken on the utterances of four American presidents: George Bush, Bill Clinton, George W. Bush and Barack Obama. This investigation concerns the issue of harnessing the Speech Acts Theory in political utterances. It also endeavors to show the overlap of these acts in speeches. In order to attain the main purpose of this investigation, some modification was applied to John Searle's Felicity Conditions and semantic rules of undertaking for the acts of intimidation, pledging and guaranteeing. Furthermore, the investigation recommends that all kinds of pronouncements from the authorities should be subjected to scrutiny with regards to language application and expressions as they may differ from one agency to another because of issues like education, culture and language skills.

Meanwhile, Misyi, Cece, and Rosaria (2018) carried out an investigation on speech as a means to authority. The goal was to evaluate the utterances of Donald Trump and Hillary Clinton in the USA Presidential candidates' debates as tools of power. The information was obtained from a video of the concluding presidential debate between Trump and Clinton in September 2016, which was transcribed into text. The data evaluation method was separated into three phases: 1) explaining the framework, 2) examining the illocutionary acts, and 3) studying the power components. The findings of the study revealed that the speakers utilised the speech act as a tool of power with categorisations of representative, commissive and expressive. Hereof, the investigators established that the speakers exhibited their power in attempting to persuade the voters to confide in them to be their president. The findings also 
revealed that the application of speech in debates as a tool of power can shape voter attitudes, particularly during elections.

There were also studies conducted on the Asian leaders. Anom et al (2014) conducted a study on the political discourse in Indonesia and Malaysia on Lahad Datu. It was reported that political interaction between Indonesia and Malaysia is lively. The interaction style was consensus without having any conflict of interest. Another study by Leong (2015) reported that communication is increasingly two-way, with the public expecting a greater engagement and interactivity with their political representatives. The Internet and social media have led to unprecedented complexity in the political communication process in Malaysia. Xie (2018) suggested political discourse analysis (PDA) as a tool to conduct speech discourse that turned out to be progressively well known and encourages thoughtfulness regarding the individuals. In the contemporary era, conducting a discourse study in English speeches has become mainstream since the English language has a significant effect at a universal level. Hence, political individuals, through speeches or debates, influence and persuade others, keeping compelling arguments to get the emotional and political support as in any types of announcement, as in Covid-19 MCO announcement.

In line with Anom, Kee and Zawawi (2014); Leong (2015); Xie (2018); Alkhirbash, Paramasivam and Zamri (2014) explored the use of logos, ethos, and pathos in persuasion speech of Mahathir Mohamad. It was found that the three rhetoricals were used in his speech. The use of these rhetorics affirmed Mahathir's integrity. A similar finding was reported by the study of Iqbal, Aslam, Aslam, Ashraf, Kashif, and Nasir's (2020) study on the use of ethos, pathos and logos on Imran Khan's (IK) speech on the MCO. It was reported that IK used stable linguistic features to persuade the minds of the people - convincing them to follow the precautionary measures as 'the only cure.' The defending arguments about semi-lockdown or smart-lockdown were well-defined in persuading the individuals; for instance, IK suggested the smart-lockdown during his first address and faced criticism from the opposition. Sibtain et al. (2020) also reported Aristotle's Rhetorical theory on the speeches of IK which concluded that the leaders consciously employ them applicably to persuade the minds of the people through media (print, social and electronic media). The above studies concluded that the leaders may use such rhetoricals to convince listeners by creating a pleasant ambience.

Therefore, the speech acts evaluation is crucial in comprehending a communication due to the fact that speech acts are the speaker's objectives delivered by speeches. Lazaraton (2001) states that speech classes at all stages are frequently framed around practical applications of language. One will be better equipped to instruct and fashion resources founded on genuine language and interactive blueprints.

Many investigations have been carried out on speech acts of presidential speeches by various presidents. However, there has been a lack of research on speech acts of prime ministers of neighboring countries during the Covid-19 pandemic and MCO.

\section{Methodology}

The data for the present study was taken from The Star/New Straits Times and the duration March 2020 to May 2020, thus there was no consent required in obtaining the data. The first announcements of the MCO were delivered by two prime ministers (Malaysia and Singapore) within the duration of 10-15 minutes. The reason for choosing the first announcement was because the speeches are extensive and informative compared to the second and third MCO announcements which were found to be very useful in investigating the variance use of speech acts in their utterances. Transcriptions of the speeches were available on the 
webpages. Thus, the researcher did not transcribe the videos. The data was analysed qualitatively (Cresswell, 2018) based on Searle's (1979) theory of speech acts, which includes five types of illocutionary acts (see Table 1). The selected speeches of the two Prime Ministers were downloaded from the Internet and carefully analysed. Next, specific sections of the speeches were selected to identify the types of speech acts that exist. In order to ensure the reliability of the transcribed data, three experts from three different universities with backgrounds in languages and linguistics verified the transcriptions and coding as well as the categorisations, and the agreement was more than 90\% (Miles \& Huberman, 1994). Li (2002); Wodak (2013) have noted that due to some rigorous circumstances on obtaining data with such limitations, even one example of excerpt could be considered to have a significant value contribution to the entire study.

\section{Analysis}

The results of the present study show that the two prime ministers were able to use different speech acts on the first MCO announcements. However, the frequencies vary, as shown in Tables 2 and 3.

TABLE 2. Frequency of the usage of the Speech Acts by Malaysia and Singapore Prime Ministers

\begin{tabular}{lcc}
\hline \multicolumn{1}{c}{ Speech Acts } & Malaysia's Prime Minister & Singapore's Prime Minister \\
\hline Assertive & $12(24 \%)$ & $20(29 \%)$ \\
Directive & $26(52 \%)$ & $20(49 \%)$ \\
Commissive & $4(8 \%)$ & $1(2 \%)$ \\
Expressive & $8(16 \%)$ & $8(20 \%)$ \\
Declaration & $0(0 \%)$ & $0(0 \%)$ \\
\hline $\begin{array}{l}\text { Total Number of } \\
\text { Speech Acts }\end{array}$ & $50(100 \%)$ & $41(100 \%)$ \\
\hline
\end{tabular}

Table 2 shows the frequency of the use of speech acts by the two prime ministers on the first COVID-19 MCO announcements. Directive speech acts were predominantly used by Malaysia's prime minister ( $n=26 ; 52 \%$ ) compared to Singapore's prime minister ( $n=20 ; 49 \%$ ). Additionally, it shows that both prime ministers did not use declaration speech acts in their announcements as they did not want to dictate the citizens due to COVID-19 pandemic. As both prime ministers approached the citizens in a pleasant manner without creating unfavourable situations. The least used speech act was the commissive speech act $(n=4 ; 8 \%)$ by both Prime Ministers. In general, there were not many differences between both prime ministers in the use of speech acts in the first MCO announcements but they were meaningful announcements to the nation on the Covid-19 pandemic. The samples of occurrences of the MCO announcements are presented in the following examples.

Yule (1996, p. 53) postulates that, nearly all directive speech acts in actuality centered on "speakers applying the acts to direct another person to implement a commission". They articulate the speaker's intentions using commands, orders, requests and suggestions. In the 
current instance, examples of directive speech acts are illustrated by the two prime ministers in their speeches and statements relating to Covid-19 which are provided in Example 1.

Directive-Example 1

\begin{tabular}{|l|l|}
\hline \multicolumn{1}{|c|}{ Malaysia's Prime Minister } & \multicolumn{1}{|c|}{ Singapore's Prime Minister } \\
\hline $\begin{array}{l}\text { The Government takes this current trend very } \\
\text { seriously, especially the rise of the second } \\
\text { wave of new infections. Our priority now is to } \\
\text { prevent the further spread of this virus within } \\
\text { the population. }\end{array}$ & $\begin{array}{l}\text { First, because Covid-19 will be with us for a } \\
\text { long time, there are baseline things that we } \\
\text { must get used to, like practising good personal } \\
\text { hygiene, adopting new social norms and } \\
\text { discouraging large gatherings, and generally, } \\
\text { maintaining some physical distance from one } \\
\text { another. }\end{array}$ \\
\hline
\end{tabular}

Example 1 from the announcement of Malaysia's prime minister 'The government...virus within the population...' ordering the nation by stating that the government looked into this matter very seriously as the Covid-19 infection has been increasing and now we have to prevent the virus from spreading in our country.

In the same vein, the Singapore prime minister said; 'first, because of Covid-19... physical distance from one another...' pleading the nation by telling, we need to practice personal hygiene, accepting new social norms and avoiding big scale gathering and maintaining the social distance.

Directives-Example 2

\begin{tabular}{|l|l|}
\hline \multicolumn{1}{|c|}{ Malaysia's Prime Minister } & \multicolumn{1}{|c|}{ Singapore's Prime Minister } \\
\hline To that end, the Government has decided to & Please work with your religious leaders to \\
implement a nationwide Restriction of & make these practical adjustments \\
Movement Order beginning 18th of March & \\
until 31st of March. This Order is enforced & \\
under the Control and Prevention of & \\
Infectious Diseases Act 1988 and the Police & \\
Act 1967, and encompasses the following. & \\
\hline
\end{tabular}

After the general statement, the prime minister voiced out the decision of MCO, which was to be enforced based on the Acts.

Directives-Example 3

\begin{tabular}{|l|l|}
\hline \multicolumn{1}{|c|}{ Malaysia's Prime Minister } & \multicolumn{1}{c|}{ Singapore's Prime Minister } \\
\hline $\begin{array}{l}\text { Finally, I pray that we will always be under the } \\
\text { protection of Allah S.W.T }\end{array}$ & $\begin{array}{l}\text { I hope Singaporeans understand that during } \\
\text { this period we may need to shorten religious } \\
\text { services or reduce our attendance at such } \\
\text { gatherings. }\end{array}$ \\
\hline
\end{tabular}

Right after the MCO enforcement, the prime minister uttered for the Supreme Almighty to protect us.

This was also followed by requesting the nation to liaise with religious leaders to practice the new norms and try to reduce service time in the respective temples.

As such, it could be seen that the content of the announcement of these prime ministers were similar. However, the way they organised the speech and the use of utterances in the 
beginning of the speech were slightly different. This could be due to the background or culture of making announcements to the nation without creating fear, panic and demotivation.

Based on this, it was discovered that there are slight differences from the present study's finding compared with that of Ayeomoni and Akinkuolere (2012), which found the use of directive as $35 \%$, while the present study shows a higher percentage by both prime ministers. This shows that the use of directive speech acts in their announcements have more impact to order and plea the nation to amplify the situation.

It is pertinent to note that when applying assertive speech acts, the speaker essentially markets his/her case, be it ideas, beliefs or important information by stressing on evidence, affirmations, inferences and explanations. As they have understood it to the best of their knowledge and capacity (Yule, 1996). The examples of incidents of assertive speech acts by both the prime ministers are shown in Example 4.

Assertive-Example 4

\begin{tabular}{|l|l|}
\hline Malaysia Prime Minister & Singapore Prime Minister \\
\hline $\begin{array}{l}\text {..tonight, I stand before you once again, to } \\
\text { update you on the current situation regarding } \\
\text { the COVID-19 pandemic that has caused great } \\
\text { distress not just in Malaysia... }\end{array}$ & \\
\hline
\end{tabular}

Example 4 shows that Malaysia's prime minister was pleased with the nation by stating that; 'Tonight, I stand...not just in Malaysia' which reflects that he has said would provide more details and elaborate the situation on the Covid-19 pandemic.

The prime minister of Singapore also alerted the nation by stating the number of cases 'at the same time...rapidly'.

Assertive-Example 5

\begin{tabular}{|l|l|}
\hline Malaysia Prime Minister & Singapore Prime Minister \\
\hline $\begin{array}{l}\text {...in Malaysia, there was a sharp rise in the } \\
\text { number of cases:190 cases recorded } \\
\text { yesterday and an additional } 125 \text { cases } \\
\text { today... }\end{array}$ & $\begin{array}{l}\text {...we have already imposed some travel } \\
\text { restrictions... }\end{array}$ \\
\hline
\end{tabular}

Furthermore, he mentioned the number of cases which have increased drastically by affirming the situation and notified that the present circumstances need to be sorted out. He added that the nation restricted to travelling.

Assertive-Example 6

\begin{tabular}{|l|l|}
\hline Malaysia Prime Minister & Singapore Prime Minister \\
\hline ...from that number, 511 are being treated. & $\begin{array}{l}\text {... hope you will work with me and colleagues } \\
\text { to keep our families safe, keep Singapore } \\
\text { secure, and move forward together... }\end{array}$ \\
\hline
\end{tabular}


At the same time, he mentioned the numbers of the people who were being treated and recovered. Furthermore, he informed the nation to follow strictly what has been imposed and alerted them to stay safe.

Assertive-Example 7

...whereas 42 have fully recovered...

At the same time, he mentioned the numbers of the people who were being treated and recovered

Assertive-Example 8

\begin{tabular}{|l|l|}
\hline \multicolumn{1}{|c|}{ Malaysia Prime Minister } & \multicolumn{1}{|c|}{ Singapore Prime Minister } \\
\hline ...the current scenario requires drastic \\
measures to be taken to resolve the situation \\
as soon as possible...
\end{tabular}

Conclusively, Malaysia's prime minister alerted the nation by stating that the exact number of Covid-19 cases have been increasing which may have instilled fear in the nation. On the other hand, Singapore's prime minister did not mention the exact number of cases but mentioned 'the number of cases is rising rapidly' which shows that the prime minister may be unsure about the number of cases but empathized with the situation. The main idea was to ensure that the nation realises the current situation of the country.

However, there were some similarities found between the two prime ministers as they mentioned that this situation needs to be resolved together. This finding manifest that in certain cases of making announcements, it is always better to inform the nation by giving factual information and elaborate the situation, thus they received comprehensive ideas of this MCO which had to be followed. A similar finding was reported by the study of Alkhirbash (2016), that in order to convince the nation, due to certain crucial matters, they have to be persuaded by providing facts and informative information. The next analysis presented the commissive speech acts.

The commissive speech acts are applied by speakers to promise the audience of some expectations in the future. They articulate the speaker's intentions, which could be an assurance, warning, repudiation or undertaking that will be carried out by the speaker only as an individual or representing others (Yule, 1996). The examples of incidences of commissive speech acts by both the prime ministers are shown in example 9.

Commisive-Example 9

\begin{tabular}{|l|l|}
\hline \multicolumn{1}{|c|}{ Malaysia Prime Minister } & \multicolumn{1}{c|}{ Singapore Prime Minister } \\
\hline $\begin{array}{l}\text {...should any of you have any questions } \\
\text { regarding this Restriction of Movement } \\
\text { Order... }\end{array}$ & $\begin{array}{l}\text { them... } \\
\text { thenfident that we can deal with }\end{array}$ \\
\hline
\end{tabular}

Example 9 shows that Malaysia's prime minister notified 'should any of you...beginning 12 noon tomorrow' the nation by requesting to contact National Operation Management if anyone needs any clarification on MCO by indicating the contact number and time. This shows that he created a hopeful situation for the nation that there is a hand to render assistance to them. This may reduce fear and panic to the nation.

Similarly, Singapore's prime minister emphasised that 'I am confident that we can deal with them'. This shows that he entrusted the nation and he expects their cooperation to 
handle the Covid-19 pandemic. The utterances from him were limited but concise and he achieved the goal in delivering the announcement.

Commissive-Example 10

\begin{tabular}{|l|l|}
\hline \multicolumn{1}{|c|}{ Malaysia Prime Minister } & Singapore Prime Minister \\
\hline ...you may contact the National Operation \\
Management Center at their hotline 03-8888 \\
2010 beginning 12 noon tomorrow...
\end{tabular}

Conversely, it was found that the prime ministers presented an amplification on the first Covid-19 MCO announcement using the commissive speech acts. It informs the nation that they are to protect the country and will be there if required and to render their assistance at any time. This shows the psychological state of both the prime ministers in their belief as they mentioned the MCO order and wanted the nation to have trust in them. Therefore, this finding is in consensus with the study of Hashim (2015), which said that the use of commissive speech acts may be limited but it has a contented message which builds trust to the listener. The next analysis is on the expressive speech acts.

In our normal life, as a matter of necessity, we indulge in interactions with other people when we communicate our thoughts in a way to enable the message to be comprehended as intended by the listeners. Typically, this occurs when the speaker expresses gratitude, expresses regret, or greets the audience. These expressive acts define the feelings of the speaker, like happiness, hurt, fondness, aversion, delight or regret (Yule, 1996). All of these expressive speech acts were utilized in the initial MCO pronouncements. The sample occurrences of expressive speech acts are provided in Example 11.

\section{Expressive-Example 11}

\begin{tabular}{|l|l|}
\hline Malaysia Prime Minister & Singapore Prime Minister \\
\hline col would like to take this opportunity to & My fellow Singaporeans, good evening. \\
convey my heartfelt thanks to all our front & \\
liners, health workers, civil servants and all & \\
parties who are working non-stop, day and & \\
night to help us resolve this COVID-19 & \\
problem...
\end{tabular}

Example 11 shows the expressive speech acts used by Malaysia's Prime Minister, 'I would like to...resolve this COVID-19 problem...'. These expressive speech acts were used as an opening for the MCO announcement. In his expressive speech acts, he mentioned the people who rendered their assistance to protect the nation 'front liners, health workers, civil servants and all parties' who were willing to support the nation to overcome Covid-19. This craft estimations of psychological conditions by these expressive speech acts portray emotions and standpoints of the speaker.

In contrast, Singapore's prime minister used 'my fellow Singaporeans, good evening' to initiate the announcements. 


\begin{tabular}{|l|l|}
\hline Malaysia Prime Minister & Singapore Prime Minister \\
\hline & $\begin{array}{l}\text {...five weeks ago, I spoke to you on our Covid- } \\
19 \text { situation... }\end{array}$ \\
\hline
\end{tabular}

In line with this, he also reminded the nation 'five weeks ago...situation' which shows he alerted the nation that they were in the Covid-19 pandemic and to be cautious. There were no utterances were found from the Malaysian prime minister.

Expressive-Example 13

\begin{tabular}{|l|l|}
\hline Malaysia Prime Minister & Singapore Prime Minister \\
\hline & ...so it is timely to update you again... \\
\hline
\end{tabular}

Additionally, he emphasised 'so it is timely to update you again', However that might be provoking to the nation. There were no utterances were found from the Malaysian prime minister.

\section{Discussion}

This finding shows that the COVID-19 pandemic has been thought-provoking and has put momentous pressure on our healthcare staff and other authorities. Nevertheless, our frontline workers continue to dedicate their time and energy to curb this pandemic. Usually, Malaysia's prime minister will humbly express his appreciation for their enormous sacrifices, invaluable devotion, commitment, and firm efforts in handling COVID-19, oftentimes endangering their own lives, for the benefit of the nation.

Whereas, Singapore's prime minister emphasized the situation differently by using those expressive speech acts. Hence, the finding is similar to Danang's (2012) study, which evaluated the speech acts in Obama's and McCain's interactions which found that expressive words play important roles in their debates.

In general, the finding shows that both prime ministers managed to establish four speech acts; assertives, directives, expressives, and commissives from the essence of the Covid-19 MCO announcements.

Language is utilized as a potent tool by those in authority to deliver national ideology, programs, etc. to the masses. Similarly, the expressions applied by the two prime ministers during the initial Covid-19 MCO shows that language is being used as a critical tool to convince their citizens of the negative effects of not following the Covid-19 related MCO promulgated by the authorities, as the illness has resulted in deaths, overwhelmed hospitals and serious economic problems worldwide. However, the speech act theory was used with the five categories of Searle's (1969).

It was found that Malaysia's prime minister primarily utilized directive speech acts $(n=26 ; 52 \%)$ in contrast to Singapore's prime minister $(n=20 ; 48.8 \%)$ when directing citizens to conform to the MCO regulations. Furthermore, the results showed that both prime ministers were unaccustomed or uncomfortable with making declarative speech acts in their statements, owing to the democratic system of governance that is followed by both countries. As such, they resorted instead to beseeching the citizens in a polite but firm way. While there were few differences in the use of speech acts by the prime ministers in their MCO statements, they did however succeed in conveying the essential messages to the people regarding the Covid-19 pandemic. The present study shows the various kinds of speech acts that can be applied subject to the nature of pronouncements to the public without causing 
fear, anxiety, and demoralization.

It was also revealed that both prime ministers used various speech acts to not only require the public to obey the Covid-19 MCO rules, but also to signify their strong commitment to safeguarding their countries.

While the substance of the various statements, speeches and appeals of the prime ministers appeared to be comparable in content, there were however some differences especially in the organization of the speeches. The introductory part of speeches by the prime ministers varied slightly which could be due to the different cultural, social, and development status of the 2 countries, although both tried not to create a sense of alarm. This could be due to background norms that preclude making announcements to the nation which can create fear, anxiety and apathy. Thus, the results of the investigation were marginally dissimilar to the findings of Ayeomoni and Akinkuolere (2012), where the usage of directive came to 35\%. The current investigation appears to indicate greater use of directive speech acts by both prime ministers. This indicates that the utilization of directive speech acts in their statements was formulated to deliver a high compliance rate among the population concerning the Covid19 pandemic.

A clear reading and analysis of the speeches, as well as statements made by the two prime ministers in the course of handling the Covid-19 pandemic, shows that Malaysia's prime minister was not averse to mentioning the exact number of people who tested positive for Covid-19 cases, even though at one stage the cases were alarmingly high. On the other hand, Singapore's prime minister took the position of not stating the exact number of cases but merely mentioning 'the number of cases is rising rapidly' which may indicate that the prime minister may be uncertain regarding the number of cases but still emphasized the gravity of the problem facing the nation.

However, there were some similarities in the speeches and statements delivered by the two prime ministers which needs to be examined. The finding reveals that, when countries are faced with critical times, such as the Covid-19 pandemic, information sharing with the public should be as detailed as possible, and factual in nature to avoid misinterpretation or poor understanding of the government's aims as well as objectives in overcoming the pandemic. This would also lead to better compliance with laws and regulations, such as the MCO. A study by Alkhirbash (2016) and Odogwu (2018), also showed that when a country faced a grave situation, it is always vital to gain public support and acceptance to rectify the situation by issuing detailed and truthful information about the problem.

Conversely, concerning commissive speech acts, the Malaysia prime minister announced 'should any of you...beginning noon tomorrow' to the nation in seeking information and explanation regarding the MCO by providing contact numbers. This indicates that he was genuinely interested in solving the problem facing the country and that he was trustworthy. This approach by the prime minister could help calm the people so as not to be fearful or panicky.

Similarly, the Singapore prime minister underscored that 'I am confident that we can deal with them'. This demonstrates that he was confident in enlisting good support from the public to tackle the Covid-19 pandemic. The expressions emanating from him were defined but succinct and accomplished the aim of conveying comprehendible information to the public.

In addition, it was found that the prime ministers amplified the initial Covid-19 MCO statements with the use of commissive speech acts. They made commitments to their 
nationals that would protect their respective nations and would leave no stone unturned to assist combat Covid-19. This shows that both the prime ministers went to extreme lengths to convince the public to abide by the MCO and have full confidence in their efforts to handle the situation. This conclusion concurs with the investigation of Hashim (2015) and Okoro (2017) that the application of commissive speech acts may not be extensive but succeed in communicating the pleaded messages to galvanize trust in the people.

When deliberating expressive speech acts, the Malaysian prime minister proclaimed 'I would like to.... resolve this COVID-19 problem'. These expressive speech acts were utilized when introducing the MCO to the nation. In his expressive speech acts, he spoke highly of people who provided help to protect the country 'front liners, health workers, civil servants, and all parties' and who strongly supported the country to contain Covid-19. This expressive speech act by the prime minister affected the people psychologically in terms of arousing their feelings.

On the other hand, the Singaporean prime minister said 'my fellow Singaporeans, good evening' to commence the statements. Following this, he also advised the country 'five weeks ago...situation' which indicates that he requested the people to be vigilant during the Covid19 pandemic. Also, he stressed that 'so it is timely to update you again' which could have upset the people.

The results demonstrate that the COVID-19 pandemic has been a challenging issue which has put tremendous pressure on our front liners, such as the health personnel and police. Nonetheless, our front liners have continued to perform their arduous tasks with dedication and vigor to overcome this pandemic. The Malaysian prime minister most respectfully expressed his appreciation to front liners for their dedication, commitment and personal sacrifice in facing Covid-19. While the Singaporean prime minister on the other hand stressed on the situation by mostly using expressive speech acts. This outcome is similar to one carried out by Danang (2012) who studied the speech acts of Obama's and McCain's exchange, in which expressive dialogue played a crucial role in their interactions.

The results established that both prime ministers applied four speech acts; assertives, directives, expressives, and commissives based on their numerous statements relating to the Covid-19 MCO. As both these leaders are proficient in English, thus they have little difficulty in articulating their statements in a precise manner to enable easy comprehension by the public. Nevertheless, other background factors may have limited the utilisation of speech acts more widely by them in contrast with leaders from western countries where English is their mother tongue (Yule, 2016; Ashani,2020).

It is the norm for people or leaders at the higher levels of authority to regularly communicate with the masses to announce programs or policies etc., to gain their support. In normal times, these speakers mostly indulge in self-promotion, announcing development programs or making promises to get the ear of the listener. Consequently, the speech act evaluation of the Covid-19 MCO statements by the prime ministers seemed to lack selfpromotion, but rather appeared to be genuine efforts at engaging with the public to surmount the grave problems brought on by the pandemic.

\section{Implication of the Study}

The findings from the present study seems to produce both theoretical and practical inferences. In the case of constructive connotation, presenting forms of expressions can be applied in the statements concerned with instructing and beseeching the nation. As 
mentioned earlier by Abdullah, Wan Ismail, Mohamad, Ab Razak, Harun, Musa, and Lee (2020) that Covid-19 created panic among the Malaysian dwellers due to the first announcement of the MCO. Therefore, by introducing those speech acts may be able to create a more pleasant atmosphere than panic, fear and demotivation for listeners. The use of speech acts; commissive speech acts can help the speaker reassure the public and maintain a calm situation within the country. Moreover, expressive speech acts will help speakers show gratitude and humbleness towards the public, increasing the effectiveness of their speech and announcements. Lastly, assertive speech acts can be used to inform listeners regarding matters related to the topic. Effective use of speech acts can help a political leader accomplish their goal and help address the nation in a good manner.

The speech acts listed above would be very useful in political communication, especially for political leaders when they deliver speeches to their citizens during the global pandemic. They can effectively prevent panic and havoc within the nation. The countries' leaders play an important role in administering the country, especially during the current pandemic and with infection rates rising. Political leaders are not the only people who can utilise speech arts in political communication.

Journalists and media are also able to use these speech acts to deliver information without causing anxiety or panic. Journalists must carefully choose their wording and use speech elements pragmatically to avoid misunderstanding and unnecessary commotion by the readers. They can use assertive speech acts paired with commissive speech acts to deliver a clear and direct image to the public.

\section{Conclusion}

In conclusion, the use of speech acts plays a critical role in political communication as they are required in order to deliver an effective and inspiring speech or announcement. This is backed by the fact that the initial statements of the two prime ministers on the Covid-19 MCO impacted greatly on the kinds of speech acts executed by them with their speeches portraying the same intentions by applying directive speech acts. This shows that directive speech acts are very crucial in the statements. Additionally, assertive speech acts assist speakers to reaffirm their positions more clearly as all are focused on swaying the listeners' thinking.

Presidential language performed a crucial part in augmenting the dominant influence of persuasion. This is because the present investigation has revealed that specific speech acts were employed in the first MCO Covid-19 statements by the two prime ministers. Both of them succeeded to a large extent in carrying the nation with them by applying directive speech to procure compliance in relation to Covid-19. Furthermore, the prime ministers utilized a few other speech acts, such as assertive, commissive, and expressive, but sparingly. Additionally, the investigation focused on affording an awareness of persuasion in the initial MCO statements by applying speech acts and stressing that the acts are applied in an effective form to attain a specific goal. Hence, the speech act theory is a very convenient and appropriate system for evaluating all kinds of statements where there are no expressions in them that need one type or speech acts or the other.

\section{References}

Abdullah, J. M., Wan Ismail, W., Mohamad, I., Ab Razak, A., Harun, A., Musa, K. I., \& Lee, Y. Y. (2020). A Critical Appraisal of COVID-19 in Malaysia and Beyond. The Malaysian Journal of Medical Sciences : MJMS, 27(2), 1-9.

https://doi.org/10.21315/mjms2020.27.2.1 
Alkhirbash. (2016). Speech acts as persuasive devices in selected speeches of Dr. Mahathir Mohammed. International Journal of English and Education, 15 (2).

Alkhirbash, A., Paramasivam, S., \& Ahmad, Z. (2014). Aspects of persuasive language in selected speeches of Mahathir Mohamad. Journal of Language and Communication, 1(1), 41-56.

Altikriti, S. (2016). Persuasive speech acts in Barrack Obama's Inaugural Speeches (2009, 2013) and The Last State of the Union Address (2016). International Journal of Linguistics, 8(2), 47-66.

Anom, E., Kee, C. P., \& Zawawi, M. J. W. (2014). Political discourse in Indonesia and Malaysia for national human security: A case study of Lahad Datu. Jurnal Malaysian Journal of Communication, 30(2), 183-200.

Ashani, M. D. (2020). Spottingand analysing the speech acts enshrined in the discourse of kamilu amooadeniyi's too beautiful to die (2015), European Journal of Applied Linguistics Studies, 2 (2), 62-92.

Ayeomoni, O. M., \& Akinkuolere, O. S. (2012). A pragmatic analysis of victory and inaugural speeches of President Umaru Musa Yar' Adua. Theory and Practice in Language Studies, 2(3), 461-468

Austin, J. L. (1962). How to do things with words. (Ed.) Jaworski, A. \& Coupland, N., The Discourse Reader, 63-75. London: Routlege.

Awani. (2020). Perutusan perdana menteri malaysia [Message from the Prime Minister of Malaysia] (video) (12:28) (in Malay). 13 March 2020. Retrieved 19 May, 2020 via Astro Awan.

Bach, K., Robert, M., \& Harnish. (1979). Linguistic communication and speech acts. Cambridge: The MIT Press

Bates, E. (1996). Language and context: The acquisition of pragmatics, Orlando, Florida: Academic Press.

Bernama (2020). Covid-19: PM outlines several key measures. Archived from the original on 14 March 2020. Retrieved 19 May, 2020 via Daily Express.

Bushra, N. R. (2015). A pragmatic analysis of commissives in some selected American political text, International Journal of Current Research, 7, (12), 23805-23814.

Creswell, J. (2018). Research design: Qualitative, quantitative, and mixed methods approaches (5th ed.) SAGE Publications, Inc.

Danang. (2012). Speech act analysis on Barrack Obama and McCain Presidential Debate 2008. (Bachelor), Univeristas Teknokrat Indonesia, Bandar Lampung

Iqbal, Z., Aslam, M. Z., Aslam, T., Ashraf, R., Kashif, M., \& Nasir, H. (2020). Persuasive power concerning covid-19 employed by Premier Imran Khan: A sociopolitical discourse analysis. Register Journal, 13(1), 208-230.

Hashim, S. S. M. (2015). Speech acts in political speeches. Journal of Modern Education Review, 5(7), 699-706

Lazaraton, A., \& Skuder P. F. (1997). Evaluating dialogue authenticity in ESL speaking texts. Journal of Annual Teaching English to the Students of Other Languages Convention, 31(2). Retrieved, 19 May, 2020 from http://www.tesol.org/conv/t97/pp/index.html.

Leong, P. (2015). Political communication in Malaysia: A study on the use of new media in politics. JeDEM 7(1): 46-71.

Leech, G. (1983). Principles of pragmatics, London: Longman Linguistics Library.

Li, W. (2002). What do you want me to say?' On the conversation analysis approach to bilingual interaction. Language in Society-Lang Soc, 31, 02-28. 
Miles, M. B., \& Huberman, A. M. (1994). Qualitative data analysis: An expanded sourcebook (Second Edi). Sage Publications.

Misyi, G., Cece, S., \& Rosaria, M. A. (2018). A pragmatic study of speech as an instrument of Power: Analysis of the 2016 USA Presidential Debate, Studies in English Language and Education, 5(1), 97-113.

Morris, C. W. (1938). Foundations of the theory of signs. Illinois: Chicago University Press.

Nunan, D. (1993). Introducing Discourse Analysis, London: Penguin,

Odogwu, N. C. (2018). Pragmatic Acts in President Muhammadu Buhari's Independence Day speech of October 1, 2017. KIU Journal of humanities, 3(3), 105-114.

Okoro, C. N. (2017). A Speech Act Analysis of the Formal Declaration of Interest for Presidency and Inaugural Speeches of President Muhammadu Buhari. Language in India, 17(10), 49-66.

Searle, J. (1979). A classification of illocutionary Acts. In: Language in society 5, pp. 1-24.

Sibtain, M., Aslam, M. Z., Khan, A., Khan, M., Atiq, M., \& Bhatti, H. (2020). Rhetorical and Persuasive Strategies Employed by Imran Khan in his Victory Speech: A Socio-Political Discourse Analysis. International Journal of English Linguistics, 10(2), 249-356. https://doi.org/10.5539/ijel.v10n2p349

Sipalan, J., \& Holmes, S. (2020). Malaysia confirms first cases of coronavirus infection". Reuters. Archived from the original on 18 February 2020. Retrieved 19 May, 2020.

Wodak, R. (2013). Discourse analysis. London, UK; Sage.

Xie, Q. (2018). Critical Discourse Analysis of News Discourse. Theory and Practice in Language Studies, 8(4), 399-403. DOI: http://dx.doi.org/10.17507/tpls.0804.06

Yule, G. (2014). The Study of Language, Fifth Edition. Cambridge: Cambridge University Press.

Yule, G. (2006). The Study of Language, Third Edition. USA: Cambridge University Press. 